\title{
PEMANFAATAN DATA SATELIT OSEANOGRAFI UNTUK MEMPREDIKSI DAERAH PENANGKAPAN IKAN LEMURU BERBASIS RANTAI MAKANAN DAN PENDEKATAN STATISTIK GAM
}

\author{
UTILIZATION OF SATELLITE OCEANOGRAPHY DATA TO PREDICT LEMURU FISHING \\ GROUND BASED ON FOOD CHAIN AND STATISTICAL GAM APPROACH
}

\author{
Eko Susilo dan Teja Arief Wibawa \\ Balai Penelitian dan Observasi Laut - KKP \\ J1. Baru Perancak Jembrana - Bali, 82251 \\ e-mail: ekosusilo@live.com
}

Diterima tanggal: 24 Oktober 2016, diterima setelah perbaikan: 7 November 2016, disetujui tanggal: 4 Januari 2017

\begin{abstract}
ABSTRAK
Ikan lemuru di Selat Bali umumnya ditangkap menggunakan pukat cincin (purse seine) atau dalam istilah lokal dikenal dengan 'slerek' yang dipimpin oleh Juru Panggung. Penentuan daerah penangkapan yang masih mengandalkan intuisi juru panggung berdampak pada penggunaan bahan bakar yang tidak efesien. Perlu adanya inovasi teknologi guna meningkatkan efesiensi operasi penangkapan ikan di Selat Bali. Salah satunya melalui pemberian informasi dugaan daerah penangkapan ikan berbasis teknologi inderaja dan pendekatan rantai makanan. Penelitian ini bertujuan memprediksi kelimpahan zooplankton, sebagai makanan utama ikan lemuru, melalui pendekatan statistik Generalized Additive Model (GAM) berdasarkan data-sata satelit oseanografi. Variabel respon berupa data kelimpahan zooplankton di perairan Selat Bali yang diukur selama periode bulan Maret - Agustus (2011-2013). Sedangkan variabel prediksi berupa data harian variabel oseanografi yang diukur oleh satelit Aqua MODIS pada hari yang sama dengan pengambilan sampel plankton. Sebanyak 7 model kelimpahan zooplankton telah dihasilkan melalui pendekatan statistik GAM berdasarkan parameter oseanografi utama yang mempengaruhi ketersediaan makanan lemuru. Hasil penelitian menunjukkan persamaan GAM yang terbaik merupakan kombinasi antara variabel suhu permukaan laut (SST), konsentrasi klorofil-a (SSC) dan Photosynthetically Available Radiation (PAR) dengan nilai deviasi terbesar (75,3\%) dan Akaike's Information Criterion terkecil $(160,197)$. Variabel SST dan PAR memiliki tingkat signifikansi yang lebih tinggi dari pada SSC. Kelimpahan zooplankton yang tinggi ditemui pada kisaran SST antara $25-26^{\circ} \mathrm{C}$, SSC antara 0,5$0,6 \mathrm{mg} / \mathrm{m}^{3}$, dan PAR antara $40-45$ einsten $/ \mathrm{m}^{2} /$ day. Nilai korelasi antara hasil prediksi kelimpahan zooplankton dan hasil tangkapan ikan lemuru sebesar 59,57\%.
\end{abstract}

Kata kunci: Generalized Additive Model, MODIS, zooplankton, lemuru, Selat Bali

\section{ABSTRACT}

Lemuru in Bali Strait are generally caught by purse seiner (local name: slerek). Juru Panggung, a man who led the fishing operation, plays an important role for determining the fishing ground areas relying on their intuition. It causes fuel un-efficient in purse seiner operation. An inovation technology is needed to improve the efficiency of fishing operations in the Bali Strait by providing fishing area information based on remote sensing technology and food chain approach. The aims of this work are to predict the zooplankton abundance, as a main lemuru's food source, through statistical Generalized Additive Model (GAM) based on satellite images. The zooplankton abundance, as a respond variable, was collected during March to August (2011-2013) in Bali Strait. While the predictor variables are daily oceanographic variables measured by the MODIS Aqua satellite on the same day by sampling plankton including sea surface temperature (SST), the sea surface chlorophyll-a (SSC) and photosynthetically available radiation (PAR). A total of seven models zooplankton abundance has been generated based on these three oceanogrphic variables. The result show that the fittest GAM equation is a combination of all predictor variables with high deviation value (75,3\%) and the lowest Akaike's Information Criterion (160,197). SST and PAR have higher significance impact on the equation than the SSC. The highest zooplankton abundance was found in area with SST $\left(25-26^{\circ} \mathrm{C}\right), \operatorname{SSC}\left(0,5-0,6 \mathrm{~m} / \mathrm{m}^{3}\right)$, and PAR (40-45 Einstein $/ \mathrm{m}^{2} /$ day).The predicted zooplankton abundance and lemuru catches have a significant relationship with good coefficient correlation (59,57\%).

Keywords: Generalized Additive Model, MODIS, zooplankton, lemuru, Bali Strait

Pemanfaatan Data Satelit Oseanografi Untuk Memprediksi Daerah Penangkapan Ikan Lemuru Berbasis Rantai Makanan Dan Pendekatan Statistik GAM - Eko Susilo dan Teja Arief Wibawa 


\section{PENDAHULUAN}

Kegiatan penangkapan lemuru (S. lemuru) di Selat Bali umumnya menggunakan pukat cincin (purse seine) atau dalam istilah nelayan lokal dikenal dengan 'slerek'. Alat tangkap ini terdiri dari 2 perahu yang dipandu oleh seorang Juru Panggung. Juru panggung memegang peranan penting dalam aktivitas penangkapan ikan, yaitu sebagai orang yang berhak menentukan lokasi penangkapan dan waktu penebaran jaring. Namun proses penentuan daerah penangkapan yang masih mengandalkan intuisi juru panggung ini menjadi salah satu faktor penyebab rendahnya tingkat efisiensi kegiatan penangkapan ikan lemuru di Selat Bali. Wiyono (2012) menyimpulkan efisiensi teknis usaha penangkapan ikan dengan alat tangkap pukat cincin di Selat Bali telah mencapai gejala overcapacity. Hal ini dicirikan sudah tidak optimalnya input produksi penangkapan ikan, salah satunya penggunaan bahan bakar minyak (BBM). Oleh karena itu diperlukan inovasi teknologi sebagai upaya meningkatkan efiseiensi kegiatan penangkapan pukat cincin dengan tetap menganut asas kelestarian dan berkelanjutan sumberdaya ikan yang bersangkutan. Salah satunya melalui Parsons, 1997). Tingkat produktivitas perairan ditentukan oleh 2 faktor fisika utama yaitu ketersediaan energi matahari dan faktor lain yang menyebabkan terangkatnya nutrien dari kolom air yang lebih dalam ke lapisan zona eufotik. Ketersediaan sinar matahari yang masuk ke dalam lautan berhubungan dengan dimensi waktu (siang, malam, dan musim) dan kondisi cuaca, yaitu sekitar 50\% energi tersebut dipancarkan dalam bentuk spektrum tampak pada panjang gelombang 400-700 nm yang juga dikenal dengan photosynthetically active radiation (PAR). Pada spectrum panjang gelombang inilah tumbuhan melakukan fotosisntesis. Intensitas PAR pada permukaan laut berkisar antara $0-2000 \mu \mathrm{E} / \mathrm{m}^{2} / \mathrm{s}$ (Lalli and Parsons, 1997). Robinson (2010) mengungkapkan PAR merupakan unsur esensial untuk menghitung tingkat produktivitas perairan. Produktivitas perairan dapat diindikasikan dengan kelimpahan fitoplankton yang dapat direpresentasikan dengan nilai konsentrasi klorofila pada perairan. Zooplankton merupakan konsumen tingkat tropik pertama yang memangsa fitoplankton, sehigga diduga pada daerah yang kaya akan fitoplankton akan dijumpai zooplankton yang melimpah pula. Selain itu suhu juga berperan penyediaan informasi prediksi daerah penangkapan ikan lemuru yang akurat.

Ikan lemuru tergolong jenis ikan pelagis kecil dalam famili clupeidae, termasuk jenis ikan pemakan penyaring (filter feeder) dengan makanan utama berupa fitoplankton dan zooplankton (Carpenter and Niem, 1999). Hal ini mengindikasikan posisi ikan lemuru sebagai konsumen primer dalam rantai makanan. Burhanuddin et al., (1984) menyampaikan komposisi makanan lemuru berupa kopepoda. Hal ini dipertegas oleh Pradini et al., (2011) yang menyebutkan jenis Coscinodiscus sp. banyak ditemukan pada lambung lemuru dan kucing. Selain itu, dalam lambung lemuru juga ditemukan Peridinium sp. sebagai makanan sekundernya. Sedangkan pada lambung protolan lebih didominasi oleh jenis Pleurosigma sp. Sartimbul et al., (2010) dan Hendiarti et al., (2005) juga menyebutkan bahwa penangkapan ikan lemuru utamanya dipengaruhi oleh ketersediaan sumber makanan utamanya.

Pola rantai makanan pada ekosistem pelagis kecil, seperti Selat Bali, cenderung sederhana (Lalli and penting dalam mengatur densitas air laut yang mendorong terjadinya pergerakan vertikal massa air yang dapat menyebabkan pengadukan kolom perairan (Lalli and Parsons, 1997). Suhu juga merepresentasikan faktor fisika yang membatasi pertumbuhan dan penyebaran organisme. Dalam perkembanganya variabel oseanografi tersebut di atas dapat diindera melalui teknologi penginderaan jauh. Salah satu satelit yang masih aktif melakukan pengukuran yaitu Aqua/Terra.

Pendugaan daerah penangkapan ikan dapat dilakukan melalui berbagai pendekatan ilmiah yang pada prinsipnya berusaha mencari keterkaitan dan kesesuaian variabel oseanografi terhadap keberadaan gerombolan ikan. Saitoh and Saitoh (2008), memetakan daerah penangkapan ikan sardine di perairan Jepang menggunakan multi sensor satelit melalui pendekatan sistem informasi geografis. Demikian halnya yang dilakukan oleh Siregar dan Hariyadi (2011) di perairan Selat Bali. Namun demikian, umumnya hubungan antara kelimpahan sumberdaya perikanan dengan dinamika faktor lingkungannya tidak linear sehingga pendekatan statistik lebih berkembang dan banyak digunakan (Zuur et al., 2009). 
Sukresno et al., (2015) memprediksi sebaran spasial tuna di Samudera Hindia menggunakan pendekatan statistik polinomial regresi berdasarkan parameter suhu perairan. Dari berbagai pendekatan statistik yang ada, generalized additive model (GAM) lebih banyak digunakan untuk pemodelan habitat suatu jenis ikan karena lebih mampu mengakomodasi hubungan yang tidak linear tersebut (Valavanis et al., 2008). Pengunaan model GAM untuk pendugaan daerah penangkapan ikan tuna telah dilakukan di beberapa wilayah laut Indonesia dengan tingkat akurasi yang lebih baik (Setiawati et al., 2015; Zainuddin et al., 2013; Wibawa, 2011). Wibawa (2012), memperkenalkan penggunaan GAM untuk mengukur pengaruh variabel oseanografi terhadap distribusi dan kelimpahan fitoplankton.

Namun saat ini belum ada yang mengembangkan metode prediksi daerah penangkapan ikan, khususnya ikan lemuru di Selat, melalui pendekatan rantai makanan. Ketersediaan data satelit oseanografi yang bersifat near realtime berpotensi untuk dijadikan sumber data untuk memprediksi daerah penangkapan ikan lemuru di Selat Bali. Penelitian ini bertujuan memprediksi kelimpahan zooplankton sebagai makanan utama ikan lemuru berdasarkan variabel oseanografi yang diperoleh dari data satelit oseanografi menggunakan pendekatan statistik GAM.

\section{BAHAN DAN METODE}

\section{Data Kelimpahan Zooplankton}

Data kelimpahan zooplankton diperoleh melalui pengambilan sampel plankton pada lokasi penangkapan pukat cincin di Selat Bali selama periode Maret - Agustus tahun 2011 - 2013. Pengambilan sampel planton mengikuti SNI.134717-1998. Analisis kelimpahan zooplankton dilakukan di Laboratorium Kualitas Perairan Balai Penelitian dan Observasi Laut menggunakan metode Sedwick-Rafter dengan mikroskop perbesaran 100 dan 200. Identifikasi zooplankton mengacu pada Yamaji (1976).

\section{Data Satelit Oseanografi}

Variabel oseanografi menggambarkan kondisi lingkungan pada saat terjadi penangkapan ikan dan pengambilan data plankton. Data satelit oseanografi diperoleh dari data citra Aqua/Terra
MODIS Level 2 harian dengan resolusi spasial 1 $\mathrm{km}$ pada hari yang sama dengan pengambilan sampel plankton yang meliputi konsentrasi klorofil-a (SSC), suhu permukaan laut (SST) dan photosynthetically active radiation (PAR). Ekstaksi variabel oseanografi dari data citra satelit memanfaatkan software SeaWiFS Data Analysis System 7.0 (SeaDAS 7.0). Selanjutnya data kelimpahan plankton dan variabel oseanografi disusun dalam dataset untuk keperluan analisis statistik. Gambaran umum kondisi oseanografi Selat Bali menggunakan data komposit musiman untuk variabel oseanografi yang sama.

\section{Model statistik GAM}

Generalized Additive Model (GAM) merupakan model semi parametrik dari regresi berganda dengan tidak terlalu mensyaratkan kenormalan distribusi data. Metode ini bersifat nonlinear dan dapat digunakan untuk mengurangi kelemahan penggunaan asumsi distribusi normal dalam parameter-parameter lingkungan yang diobservasi dan tidak ditemukannya hubungan linear antara dua variabel. Secara umum GAM menggunakan smoothing curve untuk memodelkan hubungan antara kelimpahan zooplankton (variabel respon) dengan variabel osenografi yang dalam hal ini disebut variabel prediksi.

Sebelum analisis GAM, terlebih dahulu dilakukan ekplorasi data untuk mengidentifikasi adanya data pencilan dan kolinearitas (hubungan linear) antar setiap variabel prediksi yang akan digunakan untuk menyusun persamaan GAM. Apabila antara variabel prediksi terdapat kolinearitas, maka salah satunya tidak dapat digunakan dalam penyusunan persamaan GAM. Eksplorasi data menggunakan analisis variance inflation factors (VIF) dan pairplot. VIF merupakan indeks yang mengukur besarnya peningkatan varian dari koefisien regresi akibat adanya kolinearitas antar variabel penyusunnya yang dinyatakan dalam $1 /\left(1-\mathrm{R}^{2}\right)$. Tidak adanya kolinearitas ditunjukkan dengan VIF kurang dari 3 (Zuur et al., 2007). Normalisasi sebaran data kelimpahaan zooplankton dengan menggunakan fungsi square-root transformasi dengan penambahan nilai konstanta 1 pada kelimpahan zooplankton yang bernilai nol (Zainuddin et al., 2008)

Penyusunan model GAM menggunakan pustaka mgcv packages pada perangkat lunak R. Pemilihan variabel prediksi yang mempengaruhi kelimpahan 
zooplankton didasarkan pada nilai Akaike's Information Criteria (AIC) terkecil, deviance dan tingkat signifikansi terbesar setiap model GAM yang terbentuk (Wood, 2006). Adapun persamaan dasar dari model statistik GAM yaitu:

$\operatorname{sqrt}(\mathrm{zoo}+1)=\alpha+\mathrm{s}(\mathrm{SST})+\mathrm{s}(\mathrm{SSC})+\mathrm{s}(\mathrm{PAR})+\varepsilon$

dimana $\alpha$ adalah konstanta, s(.) adalah fungsi spline smooth factor setiap variabel prediksi dan $\varepsilon$ adalah random error.

\section{HASIL DAN PEMBAHASAN}

\section{Kondisi oseanografi Selat Bali}

Kondisi oseanografi di Selat Bali dipengaruhi oleh monsoon berdasarkan sebaran komposite musiman data suhu permukaan laut, konsentrasi klorofil-a dan photosynthetically active radiation terlihat (Gambar 1-3). Pengaruh monsoon nampak jelas pada perubahan suhu permukaan laut pada musim peralihan menuju ke musim timur. Pada saat musim peralihan suhu relatif hangat dengan kisaran $28,8-30,23^{\circ} \mathrm{C}$. Kondisi suhu permukaan laut pada tahun 2011-2012 secara berurutan yaitu $28,5-29^{\circ} \mathrm{C}$ dan $28-28,5^{\circ} \mathrm{C}$. Sebaran SST pada tahun 2012 tampak lebih rendah dari tahun sebelumnya. Sedangkan pada tahun 2013 mencapai lebih dari $29,5{ }^{\circ} \mathrm{C}$ dan merupakan tertinggi dibandingkan dua tahun sebelumnya. Memasuki musim timur suhu permukaan laut mengalami penurunan yang signifikan hingga mencapai kisaran $24,75-27,64^{\circ} \mathrm{C}$. Kondisi suhu permukaan laut pada musim timur tahun 2013 tidak terlalu dingin dengan kisaran antara $26,5-27,5^{\circ} \mathrm{C}$ dibandingkan tahun sebelumnya. Bahkan di selatan Pulau Bali dan Banyuwangi suhu permukaan laut terdeteksi hingga di bawah $25^{\circ} \mathrm{C}$ pada musim timur tahun 2011-2012. Pada musim peralihan (MaretMei) kelimpahan zooplankton yang tinggi berasosiasi dengan suhu perairan yang hangat pada kisaran antara $28-29^{\circ} \mathrm{C}$, kecuali pada tahun 2013 yang terlihat pada kisaran $29,7-30^{\circ} \mathrm{C}$. Sedangkan pada musim timur (Juni-Agustus) kelimpahan zooplankton yang tinggi berasosiasi dengan suhu perairan yang dingin pada kisaran antara 25,5$26,5^{\circ} \mathrm{C}$, kecuali pada tahun 2013 yang terlihat pada kisaran $27^{\circ} \mathrm{C}$.

Rendahnya suhu permukaan laut pada musim timur merupakan indikasi terjadinya upwelling di Selat Bali. Proses upwelling mengangkat massa kolom air di bawah lapisan permukaan yang kaya nutrien dan suhu yang lebih dingin ke lapisan permukaan. Indikasi terjadinya upwelling di musim timur diperkuat oleh meningkatnya kesuburan perairan yang terindikasi dari tingginya konsentrasi klorofil-a. Pada musim timur, ekman transport di sepanjang pesisir selatan Jawa memicu terjadinya upwelling.Terangkatnya nutrien ke lapisan eufotik menyebabkan tingkat pertumbuhan fitoplankton mengalami peningkatan (Hendiarti et al., 2005). Terjadinya upwelling dapat diindikasikan oleh nilai konsentrasi klorofil-a yang lebih besar dari $0,8 \mathrm{mg} / \mathrm{m}^{3}$ dan suhu permukaan laut yang lebih rendah dari $28{ }^{\circ} \mathrm{C}$ (Hendiarti et al., 2004). Konsentrasi klorofil-a pada musim timur tahun 2011-2012 berkisar antara $1,5-3 \mathrm{mg} / \mathrm{m}^{3}$. Perairan sebelah timur dan barat Selat Bali cenderung memiliki konsentrasi klorofil-a yang tinggi, namun cenderung rendah di bagian tengah Selat Bali. Konsentrasi klorofil-a yang tinggi juga terlihat di bagian selatan Selat Bali, yang merupakan awal terjadinya upwelling. Hal yang sama ditunjukkan nilai PAR yang merepresentasikan intensitas spektrum panjang gelombang yang digunakan tumbuhan melakukan fotosintesis (Lalli and Parsons, 1997). Nilai PAR yang tinggi terlihat pada bagian selatan selat hingga masuk ke dalam selat. Namun di sepanjang pesisir Pulau Bali nilai PAR cenderung rendah yaitu kurang dari 40 einsten/m²/day. Sedangkan pada tahun 2013 konsentrasi klorofil-a cenderung lebih rendah pada kisaran antara 0,8-2 $\mathrm{mg} / \mathrm{m}^{3}$. Kelimpahan zooplankton pada musm peralihan secara konsisten sering dijumpai pada kisaran konsentrasi klorofil-a antara $0,5-1 \mathrm{mg} / \mathrm{m}^{3}$ dan PAR antara 38-39 einsten $/ \mathrm{m}^{2} /$ day. Sedangkan pada musim timur kelimpahan zooplankton secara konsisten sering dijumpai pada kisaran konsentrasi klorofil-a antara $1-1,5 \mathrm{mg} / \mathrm{m}^{3}$ dan PAR antara $41-45$ einsten $/ \mathrm{m}^{2} /$ day. Sedangkan konsentrasi klorofil-a pada musim peralihan (Maret-Mei) tahun 2011-2012 tinggi di bagian barat Selat Bali, sedangkan di bagian timur relatif rendah dengan kisaran $0,12-0,82 \mathrm{mg} / \mathrm{m}^{3}$. Nilai PAR yang tinggi terjadi pada tahun 2012 hingga mencapai kisaran lebih besar dari 45 einsten $/ \mathrm{m}^{2} /$ day. Nilai PAR yang tinggi juga terlihat pada tahun 2011 namun hanya di bagian barat Selat Bali yang mencapai kisaran 43,90-44,36 einsten/ $/ \mathrm{m}^{2} /$ day. Sedangkan pada tahun 2013 PAR cenderung rendah di dalam perairan Selat Bali.

Kondisi perairan yang dicirikan suhu dingin dan kesuburan perairan yang tinggi pada musim timur 
tahun 2011-2012 dapat menjadi indikasi intensitas upwelling pada kedua periode tersebut lebih tinggi dibandingkan dengan tahun 2013. Intensitas upwelling selain dipengaruhi oleh monsoon juga dipengaruhi oleh El Niño/Southern Oscillation/ENSO (Susanto et al., 2001) dan Indian Dipole ModelIOD (Susanto and Marra, 2005). Pada periode tahun 2011-2013, IOD lebih dominan mempengaruhi karakteristik perairan di Selat Bali.
Sebaran SST dan SSC cenderung mengikuti pola pergerakan Dipole Mode Index (DMI). Pola ini terlihat pada sebaran suhu permukaan laut di Selat Bali, dimana pada saat terjadi IOD positif (20112012) suhu perairan cenderung lebih rendah daripada kondisi normal. Sebaliknya suhu perairan cenderung lebih hangat daripada kondisi normal pada saat terjadi IOD negatif pada tahun 2013.

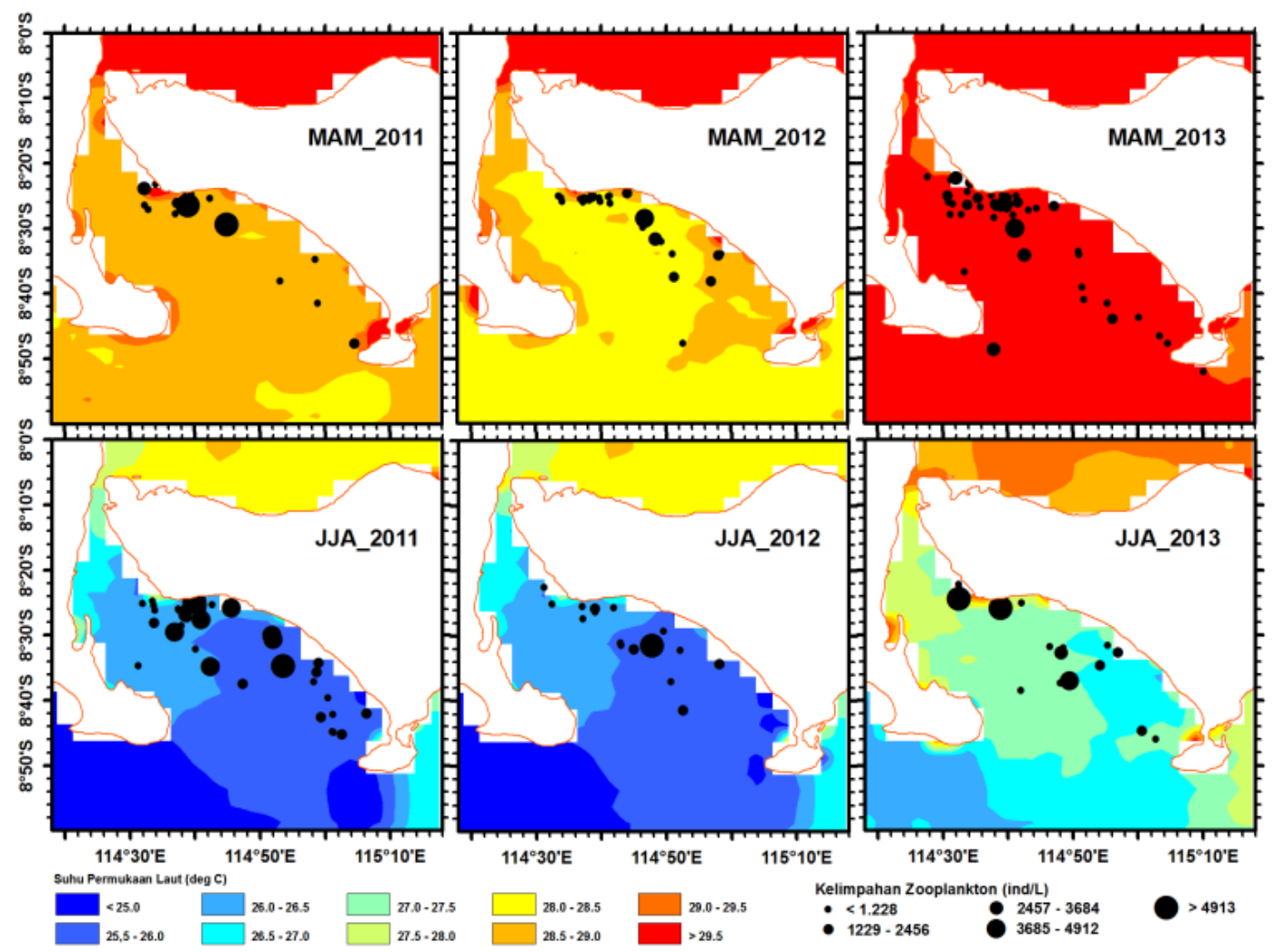

Gambar 1. Tumpang susun kelimpahan zooplankton dan komposit musiman suhu permukaan laut (SST)

Figure 1. Overlaying the zooplankton abundance and seasonally composite of sea surface temperature (SST) 


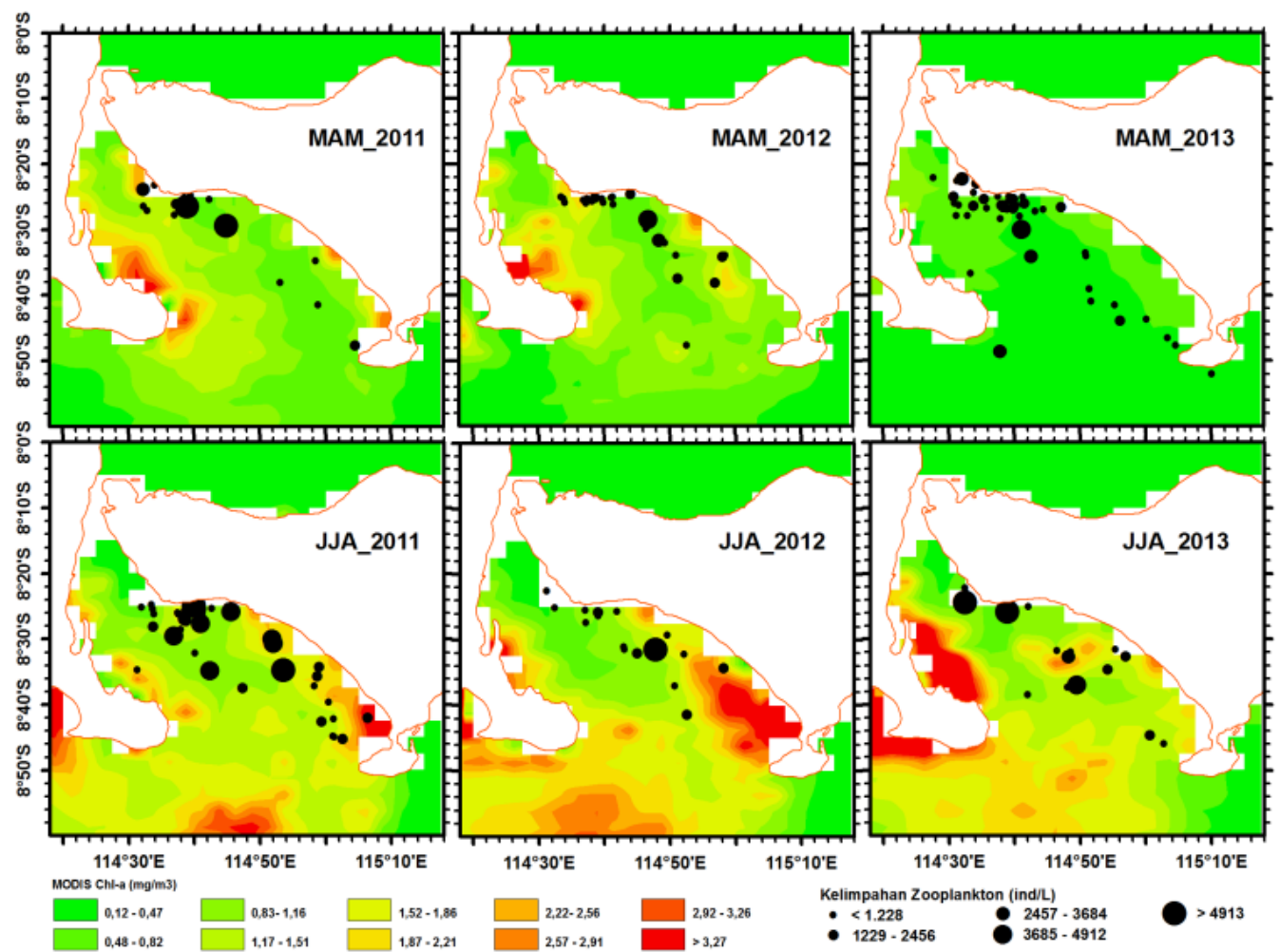

Gambar 2. Tumpang susun kelimpahan zooplankton dan komposit musiman konsentrasi klorofil-a (SSC) Figure 1. Overlaying the zooplankton abundance and seasonally composite of sea surface chlorophyll-a (SSC)

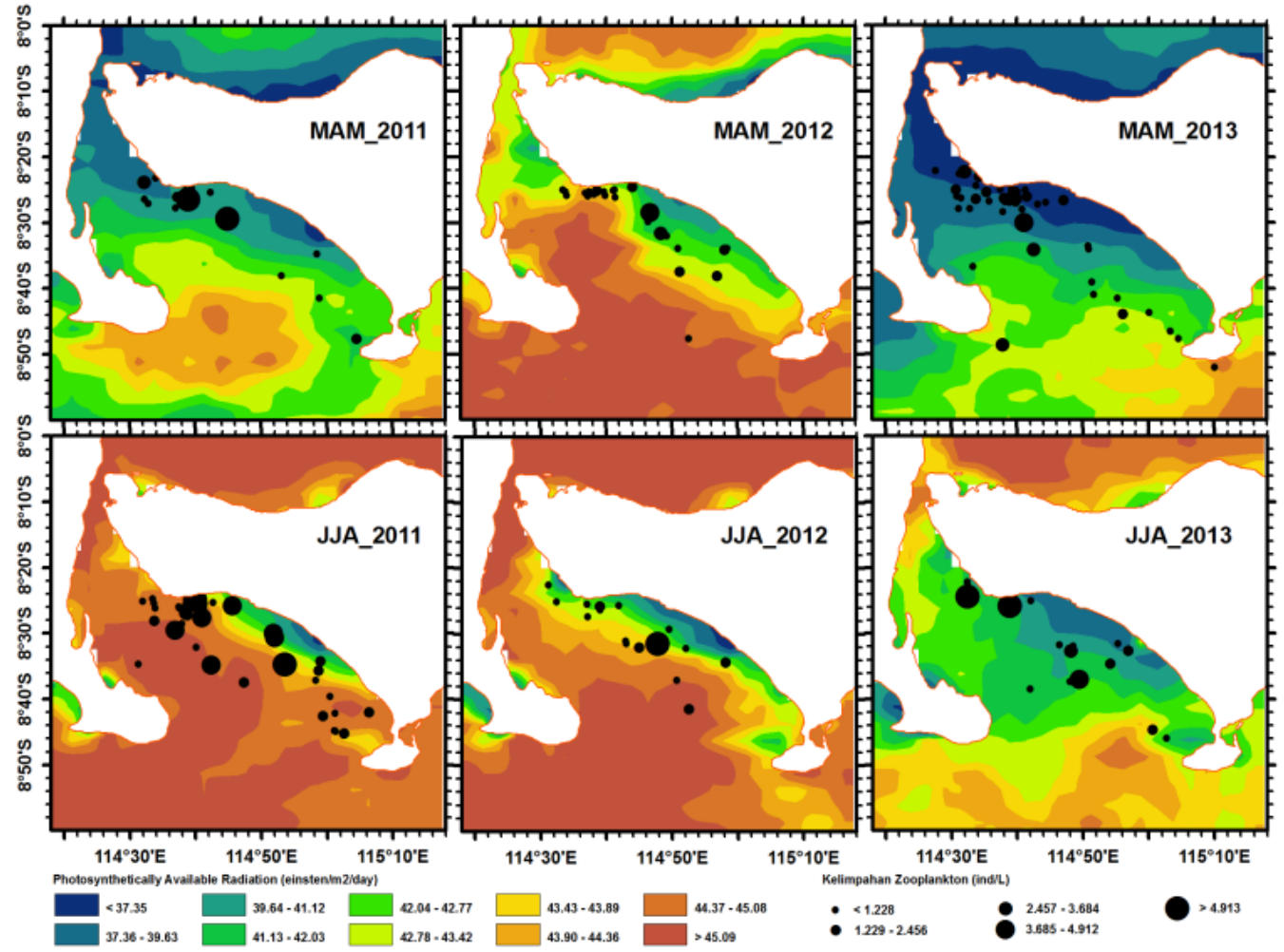

Gambar 3. Tumpang susun kelimpahan zooplankton dan komposit musiman photosynthetically active radiation (PAR)

Figure 1. Overlaying the zooplankton abundance and seasonally composite of photosynthetically active radiation $(P A R)$ 


\subsection{Model Statistik Kelimpahan Zooplankton} Hasil analisis pairplot untuk semua variabel penduga menunjukkan tidak adanya kolinearitas yang ditunjukkan dengan nilai kurang dari 0,05 (Gambar 4). Hal ini diperkuat oleh nilai variance inflation factors (VIF) untuk masing-masing variabel SSC, SST dan PAR secara berurutan 1,343, 1,073 dan 1,291. Nilai koefisien korelasi sebesar -0,26 antara variabel SSC dan SST menunjukkan hubungan yang terbalik antara keduanya, yang berarti semakin rendah nilai SST di Selat Bali akan dibarengi dengan meningkatnya konsentrasi klrofil-a. Kombinasi persamaan GAM yang terbentuk dari ketiga variabel osenaografi ditampilkan pada Tabel 1. Pemilihan persamaan didasarkan pada nilai Akaike's Information
Criteria (AIC) terkecil, deviance dan tingkat signifikansi setiap persamaan. Persamaan $\operatorname{sqrt}(\mathrm{zoo}+1) \sim \mathrm{s}(\mathrm{ssc}, \mathrm{k}=1)+\mathrm{s}(\mathrm{sst}, \mathrm{k}=4)+\mathrm{s}($ par $)$ mempunyai nilai AIC terkecil yaitu sebesar 160,197 dan nilai deviance terbesar yaitu sebesar $75,3 \%$. Nilai deviance memberikan pengertian persamaan GAM tersebut dapat menjelaskan kelimpahan zooplankton sebesar 75,3\%. Variabel SST dan PAR mempunyai kontribusi yang paling besar $(p=0,097)$ dibandingkan dengan variabel SSC $(p=0,143)$. Keterkaitan antara variabel oseanografi dengan kelimpahan zooplankton terlihat pada Gambar 5. Garis putus-putus menunjukkan selang kepercayaan 95\% untuk masing-masing variabel penduga.

Tabel 1. Hasil kombinasi persamaan GAM yang terbentuk Table 1. GAM equation combination result

\begin{tabular}{|c|c|c|c|c|c|c|}
\hline \multirow{2}{*}{ No } & \multirow{2}{*}{ Persamaan GAM } & \multirow{2}{*}{ D } & \multicolumn{3}{|c|}{ p-value } & \multirow{2}{*}{ AIC } \\
\hline & & & SSC & SST & PAR & \\
\hline 1 & sqrt $(\mathrm{zoo}+1) \sim \mathrm{s}(\mathrm{ssc})$ & 6,88 & 0,195 & & - & 240,598 \\
\hline 2 & sqrt $(\mathrm{zoo}+1) \sim \mathrm{s}(\mathrm{sst})$ & 24,3 & - & 0,099 . & - & 267,193 \\
\hline 3 & sqrt $($ zoo +1$) \sim \operatorname{s}($ par $)$ & 0,06 & - & - & 0,734 & 1786,54 \\
\hline 4 & sqrt $(\mathrm{zoo}+1) \sim \mathrm{s}(\mathrm{ssc})+\mathrm{s}(\mathrm{sst}, \mathrm{k}=3)$ & 33,2 & 0,333 & 0,050 . & - & 167,413 \\
\hline 5 & sqrt $(\mathrm{zoo}+1) \sim \mathrm{s}(\mathrm{ssc})+\mathrm{s}($ par $)$ & 41,1 & $0,049 *$ & - & 0,167 & 237,447 \\
\hline 6 & sqrt $(\mathrm{zoo}+1) \sim \mathrm{s}(\mathrm{sst})+\mathrm{s}($ par $)$ & 59,0 & - & 0,347 & 0,119 & 220,280 \\
\hline 7 & $\operatorname{sqrt}(\mathrm{zoo}+1) \sim \mathrm{s}(\mathrm{ssc}, \mathrm{k}=1)+\mathrm{s}(\mathrm{sst}, \mathrm{k}=4)+\mathrm{s}($ par $)$ & 75,3 & 0,929 & $\mathbf{0 , 0 9 7 .}$ & 0,143 & 160,197 \\
\hline
\end{tabular}

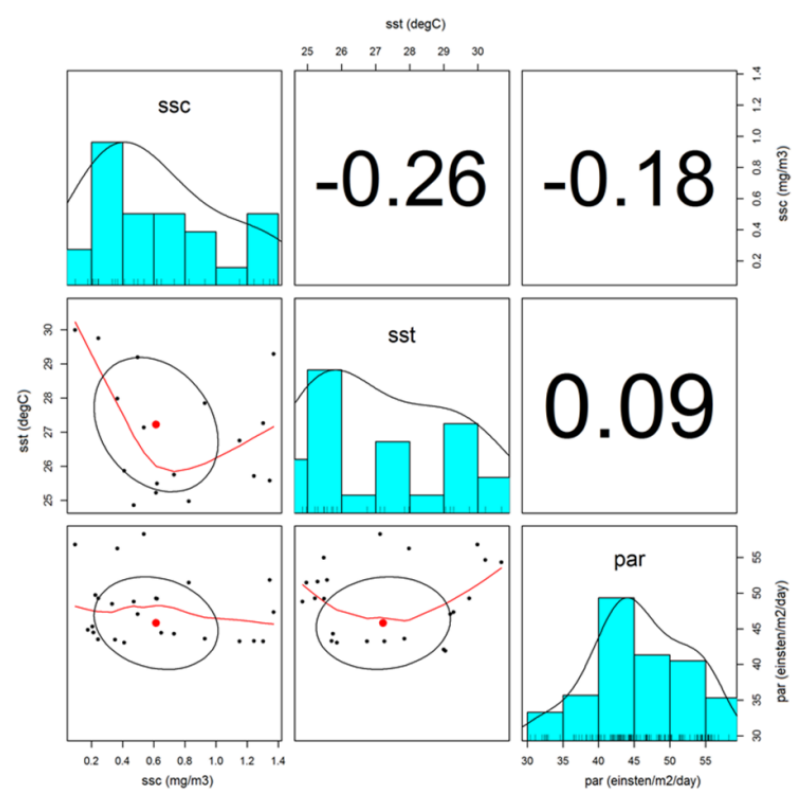

Gambar 4. Pairplot antar variabel prediksi

Figure 4. Pairplot diagram for each predictor variables 


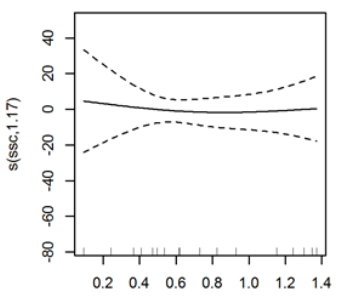

$\operatorname{ssc}(\mathrm{mg} / \mathrm{m} 3)$

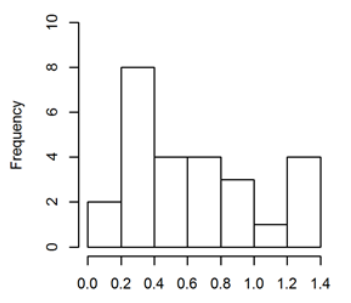

$\mathrm{ssc}(\mathrm{mg} / \mathrm{m} 3)$
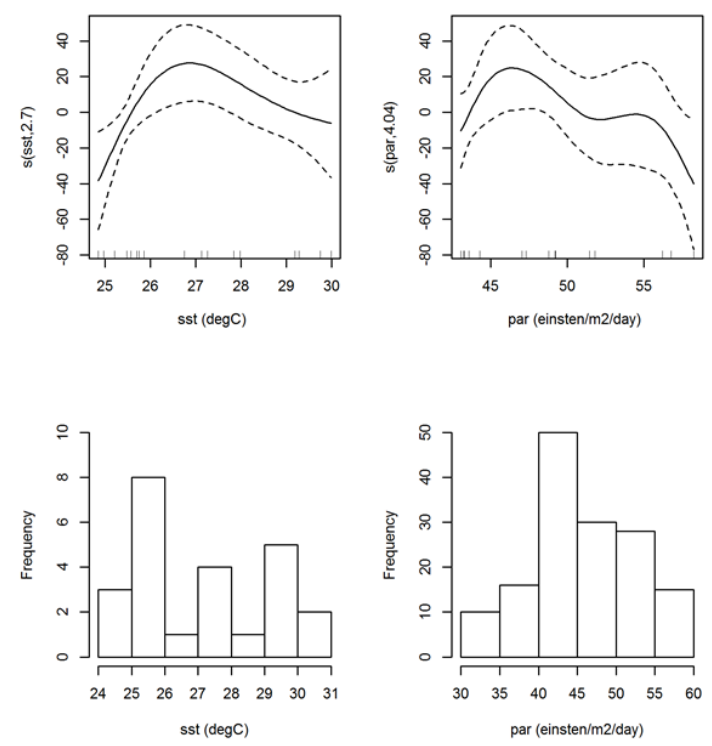

Gambar 5. Kurva smoothing hasil analisis GAM setiap variabel prediksi

Figure 5. Smoothing curve of GAM analysis result for each predictor variables

Kegiatan penangkapan ikan lemuru terjadi pada kisaran suhu permukaan laut dan PAR masingmasing $25-26^{\circ} \mathrm{C}$ dan $40-45$ einsten/ $\mathrm{m}^{2} /$ day (Gambar 6). Namun peningkatan suhu permukaan laut yang mencapai di atas $27^{\circ} \mathrm{C}$ memperlihatkan penurunan kelimpahan zooplankton. Begitu pula halnya dengan peningkatan PAR yang melebihi 47 einsten $/ \mathrm{m}^{2} /$ day. Sedangkan konsentrasi klorofil-a memberikan efek negatif terhadap kelimpahan zooplankton di perairan. Semakin tinggi nilai klorofil-a tidak serta merta diikuti dengan peningkatan kelimpahan zooplankton yang tinggi dalam perairan. Kegiatan penangkapan ikan lemuru dengan pukat cincin terjadi pada konsentrasi klorofil-a 0,5-0,7 mg/m3 (Gambar 6). Pigmen klorofil-a ditemukan di setiap jenis fitoplankton laut, namun untuk beberapa jenis pigmen yang berbeda antar setiap jenis fitoplankton menyebabkan tingkat efektifitas absorpsi radiasi sinar matahari dan proses fotosintesis berbeda untuk setiap jenis fitoplankton (Satyendranath et al., 2004). Diduga karena perbedaan komposisi tersebut, variabel SSC mempunyai kontribusi yang lebih rendah dibandingkan variabel PAR dalam pembentukan model GAM. PAR mempunyai keterkaitan yang sangat erat dengan proses fotosintesis yang dilakukan oleh fitoplankton yang merepresentasikan panjang gelombang yang digunakan tumbuhan untuk melakukan fotosintesis (Lalli and Parsons, 1997). Diatom sendiri dikenal mempunyai tingkat efektivitas proses fotosintesis yang tinggi dan merupakan sumber makanan utama zooplankton khususnya kelompok kopepoda. Sementara itu suhu permukaan laut begitu penting mengatur proses kimia dan biologi. Selain itu juga menjadi faktor pembatas yang mempengaruhi distribusi biota laut (Lalli and Parsons, 1997). Hasil pengukuran insitu oleh Agustiadi et al., (2013) menunjukkan kelimpahan plankton di perairan Selat Bali dipengaruhi oleh parameter suhu dan salinitas. Kelimpahan plankton juga dipengaruhi oleh tingginya kandungan nutrien walaupun nilai korelasinya tidak sebesar suhu dan salinitas. Pada lokasi penelitian, khususnya di paparan pesisir Bali bagian selatan merupakan area pertemuan antara massa air dari Samudera Hindia yang relatif dingin dengan maasa air dari Selat Bali yang mengakibatkan percampuran vertikal (Rintaka et al., 2014). Percampuran ini terlihat dari suhu permukaan laut yang bervariasi khususnya pada saat musim timur.

Persamaan tersebut kemudian digunakan untuk melakukan prediksi kelimpahan zooplankton di perairan Selat Bali. Prediksi yang dihasilkan dalam penelitian ini merupakan pendekatan awal dalam memahami sebaran kelimpahan sumber makanan ikan lemuru dan variabel-variabel oseanografi yang mempengaruhinya dalam skala ruang dan waktu. Hasil prediksi kelimpahan zooplankton dan hasil tangkapan ikan lemuru dapat dilihat pada Gambar 6. Kelemahan sensor MODIS yang bersifat pasif dan tidak tembus awan menyebabkan 
data kondisi oseanografi Selat Bali tidak tersedia setiap hari sebagai input data dalam validasi model. Selama periode bulan Juni-Agustus 2014 hanya terdapat 14 dataset parameter oseanografi (SST, SSC, dan PAR) yang cukup baik masingmasing 7 hari (Juni), 4 (Juli) dan 3 hari (Agustus). Hasil prediksi selanjutnya dibandingkan dengan data respon balik dari Pelabuhan Perikanan Nusantara (PPN) Pengambengan. Namun hanya terdapat 23 kegiatan penangkapan ikan lemuru pada periode yang sama, sedangkan yang bersesuaian dengan ketersediaan data osenografi hanya 9 kegiatan penangkapan. Selebihnya hasil tangkapan nelayan berupa tongkol, layang deles dan slengseng.

Prediksi tanggal 1 Juni 2014 menunjukkan tutupan awan yang tinggi hampir di seluruh Selat Bali. Kelimpahan zooplankton ditemukan di pesisir Selat Bali bagian timur yang berkisar antara 5.000 - $6.000 \mathrm{ind} / \mathrm{m}^{3}$. Pada lokasi tersebut hasil taangkapan ikan lemuru berkisar antara $2-3$ ton. Hasil prediksi pada bulan Agustus 2014 menunjukkan kelimpahan zooplankton yang tinggi di bagian utara Selat Bali. Ketersediaan sumber makanan yang melimpah menyebabkan hasil tangkapan lemuru juga tinggi. Hasil tangkapan ikan lemuru pada tanggal 19 Agustus 2014 berkisar antara 4 - 9 ton. Sedangkan hasil prediksi pada tanggal 28 Agustus 2018 menunjukkan kegiatan penangkapan ikan dilakukan pada daerah yang memiliki kelimpahan zooplankton rendah sehingga hasil tangkapan ikan lemuru pun sedikit ( $<1$ ton).

Analisis korelasi antara hasil prediksi kelimpahan zooplankton dan hasil tangkapan ikan lemuru sebesar $59,57 \%$. Hal ini menunjukkan kegiatan penangkapan ikan pada daerah yang memiliki kelimpahan zooplankton tinggi dimungkinkan akan mendapatkan ikan lemuru yang tinggi pula (Gambar 7). Hasil tangkapan ikan lemuru semakin tinggi seiring dengan melimpahnya sumber makanan, yaitu zooplankton. Namun selain faktor ketersediaan makanan, keberhasilan penangkapan ikan lemuru juga dipengaruhi oleh faktor teknis penangkapan yaitu proses penebaran jaring dan kecepatan penutupan jaring. Proses pengurungan ikan oleh pukat harus dilakukan dengan tepat dan cepat untuk mempersempit ruang gerak ikan sehingga memperkecil peluang ikan menghindar dari jaring. Pada saat ikan sudah terkurung, kantong jaring harus secepat mungkin ditutup sehingga ikan tidak melarikan diri melalui sisi bawah jaring.

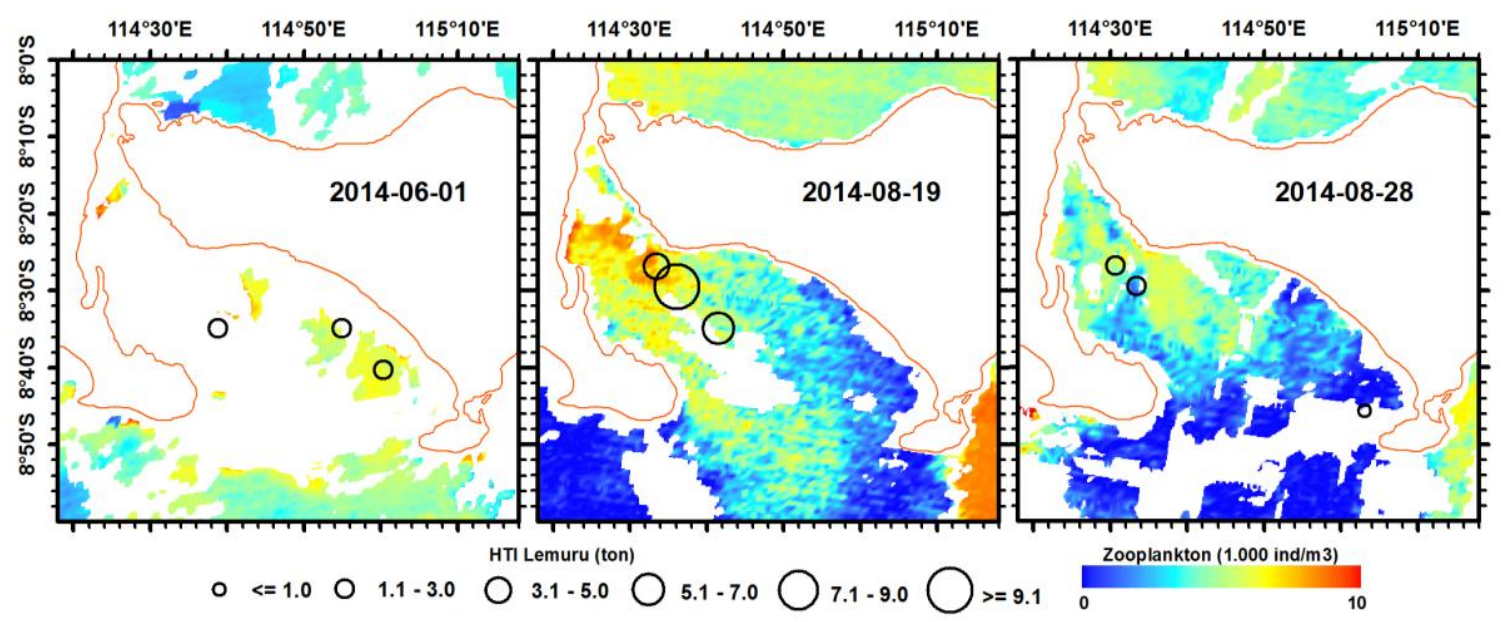

Gambar 6. Tumpang susun hasil prediksi kelimpahan zooplankton dan hasil tangkapan ikan lemuru Figure 6. Overlaying the predicted zooplankton abundance and lemuru catches 


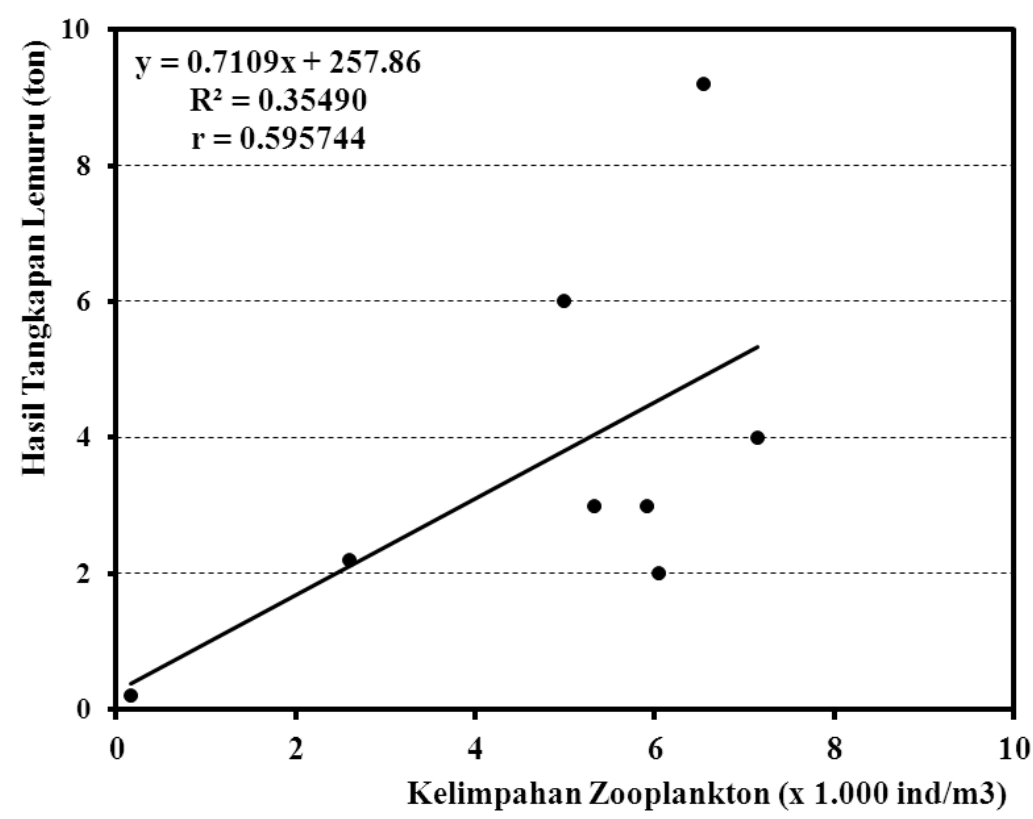

Gambar 7 Korelasi hasil prediksi kelimpahan zooplankton dan hasil tangkapan ikan lemuru

Figure 7. Correlation between the predicted zooplankton abundance and lemuru catches

\section{KESIMPULAN DAN SARAN}

Keberadaan ikan lemuru sebagai konsumen primer dalam rantai makanan dapat dijadikan dasar dalam penyusunan informasi daerah penangkapannya. Sebanyak 7 model kelimpahan zooplankton telah dihasilkan melalui pendekatan statistik GAM berdasarkan parameter oseanografi utama yang mempengaruhi ketersediaan makanan lemuru. Kelimpahan zooplankton dapat diprediksi melalui kombinasi variabel suhu permukaan laut (SST), konsentrasi klorofil-a (SSC) dan Photosynthetically Available Radiation (PAR) sesuai dengan persamaan $\operatorname{sqrt}(z o o+1)=s(s s c$, $\mathrm{k}=1)+\mathrm{s}(\mathrm{sst}, \quad \mathrm{k}=4)+\mathrm{s}(\mathrm{par})$. Persamaan ini dapat menjelaskan kelimpahan zooplankton sebesar $75,3 \%$ dari populasi sampel yang digunakan. Zooplankton cenderung melimpah pada kisaran SST antara $25-26^{\circ} \mathrm{C}$, SSC antara $0,5-0,7 \mathrm{mg} / \mathrm{m}^{3}$, dan PAR antara 40-45 einsten $/ \mathrm{m}^{2} /$ day. Variabel SST dan PAR memiliki tingkat signifikansi yang lebih tinggi dari pada variabel SSC. Korelasi hasil prediksi kelimpahan zooplankton dan hasil tangkapan ikan lemuru yang cukup tinggi memungkinkan pendekatan ini dapat digunakan untuk menentukan daerah penangkapan ikan lemuru di Selat Bali. Namun demikian perlu dilakukan kegiatan validasi kelimpahan zooplankton dan eksperimen penangkapan (experimental fishing) untuk menguji keakuratan informasi yang dihasilkan oleh model ini.

\section{UCAPAN TERIMA KASIH}

Ucapan terima kasih disampikan kepada I Nyoman Suranan dan Yuli Pancawati yang telah membantu dalam proses identifikasi jenis plankton.

\section{DAFTAR PUSTAKA}

Agustiadi, T., Hamzah, F., \& Trenggono, M. (2013). Struktur komunitas plankton di perairan Selat Bali. Omniakutika, 12(17), 1-8.

Burhanuddin, Hutomo, M., Martosewojo, S., \& Moeljanto, R. (1984). Sumberdaya ikan lemuru. Jakarta: Lembaga Ilmu Pengetahuan Indonesia.

Carpenter, K.E., \& Niem, V.H. (1999). FAO species identification guide for fishery purposes. The living marine resources of the Western Central Pacific. Volume 3. Batoid fishes, chimaeras and bony fishes part.1 (Elopidae to Linophrynidae). Roma: Food and Agriculture Organization.

Hendiarti, N., Suwarso, Aldrian, E., Amri, K., Andiastuti, R., Sachoemar, S.I., et al. (2005). Seasonal variation of pelagic fish catch around Java. Oceanography, 18(4), 112-123.

Hendiarti, N., Siegel, H., \& Ohde, T. 2004. Investigation of different coastal processes in Indonesian waters using SeaWiFS data. Deep-Sea Research II, 51, 85-97. 
Lalli, C.M., \& Parsons T.R. (1997). Biological oceanography: An introduction (2nd ed.). Oxford: Elsevier Butterworth-Heinemann.

Pradini, S., Rahardjo, M.E., \& Kaswadji, R. (2011). Kebiasaan makanan ikan lemuru (Sardinella lemuru) di perairan Muncar, Banyuwangi. Jurnal Iktiologi Indonesia, 1(1), 41-45.

Rintaka, W.E., Setiawan, A., Susilo, E., \& Trenggono, M. (2014). Variasi sebaran suhu, salinitas dan klorofil terhadap jumlah tangkapan lemuru di perairan Selat Bali saat muson tenggara. Prosiding Pertemuan Ilmiah Nasional Tahunan X ISOI 2013, 20-31. Jakarta: Ikatan Sarjana Oseanologi Indonesia.

Robinson, I.S. (2010). Discovering the ocean from space: the unique applications of satellite oceanography. UK: Springer-Verlag Berlin Heidelberg.

Saitoh, K., \& Saitoh, S. (2008). Prediction of sardine fishing ground as determined by multi-sensor remote sensing and GIS. International Journal of Remote Sensing and Earth Science, 5, 67-83.

Sartimbul, A., Nakata, H., Rohadi, E., Yusuf, B., \& Kadarisman, H. P. (2010). Variations in chlorophyll-a concentration and the impact on Sardinella lemuru catches in Bali Strait, Indonesia. Progress in Oceanography, 87(1-4), 168-174

Satyendranath, S., Watss, L., Devred, E., Platt, T. Caverhill, C., \& Maass, H. (2004). Discrimination of diatoms from other phytoplankton using ocean-colour data. Marine Ecology Progress Series, 272, 59-68.

Siregar, V., \& Hariyadi. (2011). Identifikasi parameter oseanografi utama untuk penentuan daerah penangkapan ikan lemuru dengan menggunakan citra satelit MODIS di Perairan Selat Bali. Jurnal Akuatik,1(1), 32 - 38.

Sukresno, B., Hartoko, A., Sulistyo, S., \& Subiyanto. (2015). Empirical Cumulative Distribution Function (ECDF) analysis of Thunnus sp. using ARGO float sub-surface multilayer temperature data in Indian Ocean south of Java. Procedia Environmental Sciences, 23, 358 - 367.

Susanto, D., Gordon, A.L., \& Aheng, Q. (2001). Upwelling along the coasts of Java and Sumatra and its relation to ENSO. Geophysical Research Letter, 28(8), 1599-1602.

Susanto, D., \& Marra, J. (2005). Effect of the 1997/98 El Niño on chlorophyll a variability along the southern coasts of Java and Sumatra. Oceanography, 18(4), 124-127.

Valavanis, V.D., Pierce, G.J., Zuur, A.F., Palialexis, A., Saveliev, A., Katara, I., et al. (2008). Modelling of essential fish habitat based on remote sensing, spatial analysis and GIS. Hydrobiologia, 612, 520.
Wibawa, T.A. (2011). Prediksi sebaran daerah potensial penangkapan tuna mata besar dengan data satelit oseanografi, argo float, model statistika dan GIS. Makalah disajikan dalam Seminar Kelautan Internasional, Denpasar: Balai Penelitian dan Observasi Laut.

Wibawa, T.A. (2012). Pemanfaatan data harian sensor MODIS Aqua/Terra untuk memperkirakan sebaran kelimpahan diatom di Selat Bali. Jurnal Kelautan Nasional, 7(2), 120-132.

Wiyono, E.S. (2012). Analisis efisiensi teknis penangkapan ikan menggunakan alat tangkap purse seine di Muncar, Jawa Timur. Jurnal Teknologi Industri Pertanian, 22(3), 164-172.

Wood, S.N. (2006). Generalized additive models: An introduction with $R$. Chapman and Hall/CRC.

Yamaji, I. (1976). Illustration of the marine plankton of Japan. Japan: Hoikusha Publishing Co., LTD.

Zainuddin, M., Nelwan, A., Farhum, S.A., Najamuddin, Hajar, M.I.H., and Kurnia, M. 2013. Characterizing potential fishing zone of skipjack tuna during the southeast monsoon in the Bone Bay-Flores Sea using remotely sensed oceanographic data. International Journal of Geosciences, 4, 259-266.

Zuur, A.F., Ieno, E.N., \& Smith, G.M. (2007). Analysing ecological data. Statistics for biology and health. USA: Springer Science + Business Media, LLC.

Zuur, A.F., Ieno, E.N., Walker, N.J., Saveliev, A.A., \& Smith, G.M. (2009). Mixed effects models and extensions in ecology with $R$. USA: Springer. 